\title{
Erythrocyte: Bacteria killer and bacteria pray
}

\author{
Hayk Minasyan \\ Private Laboratory of Immunology, Yerevan, Armenia
}

Email address:

haykminasyan@rambler.ru

\section{To cite this article:}

Hayk Minasyan. Erythrocyte: Bacteria Killer and Bacteria Pray. International Journal of Immunology. Special Issue: Antibacterial Cellular and Humoral Immunity. Vol. 3, No. 1-1, 2015, pp. 1-7. doi: 10.11648/j.iji.2015030101.11

\begin{abstract}
Erythrocyte is human blood main bactericidal cell. During movement in blood stream erythrocytes are triboelectrically charged by rubbing to each other and vessel walls and this charge automatically attracts and keeps bacteria on erythrocyte surface. Bacteria fixation on erythrocyte membrane activates the receptors of the membrane and stimulates trans membrane releasing of oxygen from oxyhemoglobin that causes bacteria oxidation and killing. If bacteria survive oxidation and enter erythrocyte they are exposed to higher concentration of oxygen (oxygen reactive species). Very few bacteria survive inside erythrocytes, but some can survive because of lack of oxygen inside erythrocyte and/or bacteria resistance to oxygen reactive species. Killed inside erythrocyte bacteria are released back to plasma and are digested in liver and spleen by local macrophages. Erythrocytes that are injured by bacteria and/or contain killed or living bacteria are destroyed in spleen. Erythrocytes out of bloodstream (in case of hemorrhage, extravasation in lobar pneumonia, etc.) after bacteria engulfment can't kill bacteria because of lack of oxyhemoglobin and become bacteria container providing both nutrients (protein, iron, carbohydrates, etc.) for bacteria growth and some defense against phagocytes and antibodies. In bloodstream erythrocyte is bacteria killer, out of bloodstream it is bacteria pray.
\end{abstract}

Keywords: Erythrocyte, Bacteria, Blood, Bacteremia, Sepsis, Liver, Spleen

\section{Introduction}

Erythrocytes are the main bactericidal cells in human blood. Bloodstream clearance from pathogens is performed by erythrocytes. They attract, engulf, kill and then push killed microorganisms back to blood plasma [1]. Leukocytes can't perform phagocytosis in blood stream and leucocytes do not participate in blood bacteria clearance. Blood velocity prevents phagocytosis because there is no time for leukocyte to recognize and catch bacteria [2]. During motion in bloodstream erythrocytes become charged by triboelectric effect. This charge attracts bacteria and fixes them on the surface of erythrocyte and then bacteria are engulfed and killed by hemoglobin oxygen. In bloodstream leukocyte thin wrinkled elastic membrane can't be charged by triboelectric effect and as a result leukocyte can't catch bacteria by means of electrostatic attraction force. Leukocytes engulf and kill bacteria out of blood circulatory system, particularly, in tissues, lymph nodes, slow velocity lymph, etc. [2]. Erythrocyte and leukocyte are bactericidal partners: the first kills bacteria in bloodstream; the second kills them locally, out of blood circulation. As bacteria killer erythrocytes have many advantages versus phagocytes, for instance, their volume fraction constitutes $99.9 \%$ of blood cells, they kill microorganisms without being injured, they are resistant to pathogens, they live much longer, pathogens can't proliferate in erythrocytes and the latter kill bacteria more effectively than leukocytes. [1].

\subsection{Triboelectric Charging}

Erythrocyte bactericidal power depends upon its membrane triboelectric charge and the amount of oxygen (oxyhemoglobin) inside erythrocyte.

Erythrocyte membrane triboelectric charge provides bacteria attraction, fixation on the surface of the membrane and engulfing. Triboelectric charging is determined by rubbing of erythrocytes to each other and vessel walls. The higher is blood flow velocity and its acceleration and deceleration, the more is erythrocyte triboelectric charging [2]. In systemic circuit blood velocity decreases from aorta to big arteries, small arteries, arterioles, becomes minimal in capillaries and gradually increases from venules to small veins, large veins and venae cava [3, 4]. Blood flow is faster 
in systole than in diastole [5]. In the aorta near the valves the blood current varies in rapidity (fast acceleration and fast deceleration) because the flow through the aortic orifice is intermittent. It means that maximal triboelectric charging occurs in heart ventricles (chambers), in aorta and big arteries providing rapid attraction and engulfing of bacteria by erythrocytes. But attracting and engulfing of bacteria are only the first step of erythrocyte bactericidal function: bacteria should be killed inside erythrocyte by means of hemoglobin's oxygen.

\section{Results}

\subsection{Bactericidal Function of Oxygen and Catalases}

Oxyhemoglobin is formed in the pulmonary capillaries when heme binds to oxygen. A gram of hemoglobin binds $1.34 \mathrm{~mL} \mathrm{O} 2$ increasing the amount of oxygen in blood seventy-fold. Human hemoglobin molecule binds four molecules of oxygen [6,7]. There are a taut (tense) and relaxed forms of hemoglobin. Different factors (blood $\mathrm{pH}$, the amount of $\mathrm{CO} 2$ and 2,3-Bisphosphoglyceric acid, partial pressure of oxygen, etc.) determine hemoglobin capacity to bind oxygen $[8,9]$.

Erythrocytes are exposed to oxygen high concentrations and as a result high concentration of hydrogen peroxide is generated inside erythrocyte. Erythrocyte is tolerant to hydrogen peroxide because erythrocyte is lack of intracellular components and, besides, catalase co-localized with hemoglobin protects the latter from hydrogen peroxide [10]. Catalase deficit causes hemoglobin oxidization and hemolysis or aggregation of erythrocytes [11].

Erythrocyte main weapon for bacteria killing are reactive oxygen species . Different cells protect themselves against reactive oxygen species by means of catalases, lactoperoxidases, superoxide dismutases and other enzymes. Bacteria have various antioxidant defenses for survival [12, 13]. There are three protein families in bacteria that catalyze dismutation. Two of them are typical catalases: the first is found in Archaeabacteria, Eubacteria, Plantae, Protista, Fungi, Animalia, the second - catalase-peroxidases - are absent in animals and plants and have both peroxidatic and catalatic action [14]. Manganese catalases are the third group. Catalyzing the same reaction $(2 \mathrm{H} 2 \mathrm{O} 2 \rightarrow 2 \mathrm{H} 2 \mathrm{O}+\mathrm{O} 2)$, these protein families are quite different in structure, localization and reactivity $[15,16]$. Manganese catalases are found in many microbes and they are one of alternatives to hemecontaining catalases [17, 18, 19]. Catalases are extremely active enzymes: each second their one molecule degrades hydrogen peroxide million molecules to oxygen and water [20]. NADH peroxidase (Npr) may be produced by some bacteria. This enzyme also may be an alternative to catalase when heme is not available [21]. Bacteria that cannot synthesize heme (for example, E. faecalis ) use heme environmental sources [15]. Thus, bacteria have different mechanisms to withstand reactive oxygen species attack inside erythrocyte, but relatively long term survival of bacteria in blood plasma and inside erythrocyte also depends upon bacteria metabolism (aerobe, anaerobe, speed of growth and proliferation), capsule production, morphology of bacterial cell membrane (thickness, structure, composition), etc.

The amount of reactive oxygen species in erythrocyte progressively diminishes in capillaries where hemoglobin releases the oxygen into the tissue. Bactericidal potential of erythrocyte is maximal in the lungs, at the alveolar-capillary interface where the partial pressure of oxygen is high and the oxygen binds readily to hemoglobin. In this sense the lungs may be considered the main organ that provides bloodstream clearance from pathogens. Bactericidal potential of erythrocytes is minimal in venae cava superior and inferior. The concentration of venous blood oxygen is dependent upon the amount of arterial blood oxygen, the amount of oxygen taken by tissues and blood cardiac output [22, 23]. The same bacterium may be killed by reactive oxygen species inside erythrocyte in arterial blood and can survive inside erythrocyte in venous blood, but this survival is short term, because one complete cycle of erythrocyte circulation is approximately 20 seconds [24-26]. Triboelectric charging of erythrocytes in venous blood is enough for attraction and engulfing bacteria, but the amount of oxygen (more correctly - reactive oxygen species) inside erythrocyte is not enough for bacteria killing, but this problem is usually successfully solved in the lungs during erythrocyte oxygenation. Venous blood erythrocytes also attract and engulf bacteria from lymph that enters venous blood from terminal lymphatic vessels and then kill them during oxygenation in the lungs. But hemoglobin oxygenation and high concentration of reactive oxygen species inside erythrocyte not always guarantee bacteria killing.

\subsection{Anaerobe and Aerobe Bacteria in Bloodstream}

Reactive oxygen species effectively kill anaerobe bacteria and as a result bacteremic episodes caused by anaerobes are unusual [27-29]. Anaerobes are the cause of bacteremia in adults only from $8 \%$ to $11 \%$ of cases and they are rare present in blood cultures [30]. Even in ulcerative colitis with the opportunity of massive penetration of anaerobes to bloodstream suppurative pylephlebitis with bacteremia is rare. A review of 783 cases of chronic ulcerative colitis and ileitis did not reveal bacteremia even in a case [31]. Later studies also showed that extracolonic Clostridium difficile infections, particularly bacteremia, occursd very rarely [32-36]. Clostridium ramosum, Clostridium perfringens and other clostridia also cause bacteremia very rare [37-38]. There is no data regarding C. tetani bacteraemia [39].

After tooth extractions more than 120 anaerobe species were found in blood [40-43]. The frequency of anaerobe bacteremia after tooth extraction is $39-100 \%$ [44-47]. All these bacteria are cleared from bloodstream during an hour [43, 44]. Eating, chewing, brushing the teeth, using toothpicks, etc. also cause short-term bacteremia [45]. During tooth brushing in $23 \%-57 \%$ of adults billions of bacteria enter the bloodstream [42]. 
Nontyphoidal Salmonella causes bacteremia in $1 \%$ of enteric infections. Among different serotypes, the most invasive are Salmonella typhimurium, Salmonella cholerae suis and Salmonella Virchow [48, 49]. At the same time if a bacterium is facultatively anaerobic and produces catalase, it may better withstand reactive oxygen species action and often cause bacteremia. S. enterica serovar Typhi (S. Typhi) and S. Paratyphi A cause typhoid fever and bacteremia without septic shock and neutrophilia [50, 51].

Aerobes are more resistant to erythrocyte reactive oxygen species attack, but catalase production is more important for survival inside erythrocyte. Catalase provides bacteria survival by hydrogen peroxide neutralization [52]. All Staphylococcus species (except Staphylococcus saccharolyticus and Staphylococcus aureus subsp. anaerobius) produce catalase [53, 54]. Facultative anaerobe Staphylococcus aureus causes community-acquired and hospital-acquired bacteremia with highest morbidity and mortality $[55,56]$. Another, may be no less effective (than catalase production) mechanism of erythrocyte killing evasion is capsule production.

\subsection{Bacterial Capsule as an Electric Insulator}

Producing capsule and capsular polysaccharides pathogens simultaneously affect two factors that provide pathogen attraction and fixation on erythrocyte membrane. Acting as an insulator, the capsule prevents: (a) pathogen body triboelectric electrification; (b) interaction and attraction of pathogen charge (zeta potential) and erythrocyte surface electric charge. The thicker is the capsule, the more significant is its protective effect against erythrocyte attraction and fixation. The capsule of some pathogens acts as insulating tape wrapped around bacterial body whereas the capsules of other pathogens provide more prolonged but less intensive electron exchange between bacterium and erythrocyte as a result decreasing the attraction between them. Pathogens may lose their capsules in high velocity bloodstream because of capsule mechanical tearing away. In case of electric fixation on erythrocyte surface bacteria may escape fixation via leaving the capsule. The capsule provides bacteria survival in bloodstream and escaping erythrocyte attraction and engulfment, so invasive bacteria as a rule are protected by a capsule $[57,58]$. In bloodstream the capsule predominantly acts as an insulator regarding pathogen's own and erythrocyte electric charge interaction, out of blood circulatory system it acts as an antiphagocytic and serumresistance factor. All pathogens that cause bacteremia and sepsis are able to escape erythrocyte bactericidal action by means of capsule formation. Bacterial strains capable of capsular production are Escherichia coli $[59,60]$, Staphylococcus aureus [61- 63], Klebsiella pneumonia [64], Haemophilus influenza [65, 66], Neisseria meningitides [67], Streptococcus pneumonia [68, 69], Pseudomonas aeruginosa $[70,71]$ and some others. Oral microbiota (Porphyromonas gingivalis, Bacteroides forsythus, Streptococcus sanguinis, Streptococcus mutans and others) that enter bloodstream and participate in various systemic diseases ((subacute bacterial endocarditis , glomerulonephritis, rheumatoid arthritis, myocardial infarction, carotid and coronary atheromas, etc.) also produce a capsule for escaping erythrocyte engulfing [72-75].

\subsection{Bacteria Slow Metabolism Provides "Electric Invisibility"}

Slow metabolism and growth make bacteria "invisible and uncatchable" for erythrocyte because the latter rapidly attracts and engulfs bacteria by means of interaction of its surface static electric charge with zeta-potential of bacterial cell membrane. Bacteria slow metabolism does not generate enough electric potential for interaction with erythrocyte electric charge and as a result bacteria are not attracted and fixed on the surface of erythrocyte. Tuberculosis and leprosy are good illustration of this phenomenon. In the past Mycobacterium tuberculosis bacteremia was asymptomatic and was providing infection dissemination [76, 77]. At present the situation is the same $[78,79]$. M. tuberculosis cell wall contains $60 \%$ of lipids that include cord factor, wax-D and mycolic acids. Although the wall of M. tuberculosis is thick and dense, it is hydrophobic because of lipids and so it is not triboelectrically charged enough for attraction by erythrocyte. The lipids of M. tuberculosis cell wall provide the bacterium survival inside erythrocyte by means of protecting from lethal oxidation. $M$. tuberculosis can survive in $\mathrm{H} 2 \mathrm{O} 2 \mathrm{mmol}$ concentrations $[80,81]$. But not only cell wall lipids protect the bacterium from oxidation. Protective effect is also provided by mycobacterial catalase-peroxidase protein (KatG) and the alkyl hydroperoxide reductase protein (AhpC) [82]. It should be taken into account that $\mathrm{M}$. tuberculosis is obligate aerobe and its metabolism is accommodated to oxygen high concentrations.

Continuous bacteremia is present in leprosy but often it is difficult to reveal because Mycobacterium leprae grows and multiplies extremely slowly, besides it is an intracellular parasite and circulates in bloodstream in limited amount [83$85]$.

\subsection{Bacteria wall Features Affect Bloodstream Survival}

Bacterial wall thickness and structure also influences attraction, engulfment and killing of bacteria by erythrocyte. Gram stain is determined by bacteria wall structure, composition and thickness. The wall of Gram-positive bacteria is thicker $(20-80 \mathrm{~nm})$, porous, with single lipid bilayer (monoderm) and contains $90 \%$ of peptoglycan, whereas Gram-negative bacteria wall is thinner $(10 \mathrm{~nm})$, chemically more complex, less permeable (with two layers diderms), it is composed predominantly from lipopolysaccharides and contains only $5-20 \%$ of peptidoglycan [86-88]. Despite their thicker peptidoglycan layer ( it is relatively porous and so can't be permeability barrier for reactive oxygen species), gram-positive bacteria are more easily killed inside erythrocyte than Gram-negative bacteria. Bacterial wall of gram-positive cells is denser and so it is more triboelectrically charged in bloodstream. As a 
result, gram-positive bacteria are more attracted by erythrocytes than Gram-negative bacteria.

Some bacteria (for example, S. aureus ) form conglomerates in site of infection but entering bloodstream the cells of conglomerate are mechanically separated by inertia and rubbing force and travel in plasma as a group of a few cells or a cell. Triboelectric charging of bacterial wall inhibits active transport and passive diffusion of nutrients and waste products through bacterial wall and metabolism and growth of bacteria stops or slows down.

\subsection{Bacteria Survival Inside Erythrocyte}

After bacterium engulfment by erythrocyte two scenarios are possible: (a) bacterium is killed by reactive oxygen species inside erythrocyte; (b) bacterium survives and starts to grow and multiply, using erythrocyte as some kind of Petri dish with cultivation media. The second scenario is probable in venous blood because of lack of oxyhemoglobine there and it is quite often in case of hemorrhage because erythrocytes in tissues and cavities are void of oxyhemoglobine and become a good source of nutrients (protein, iron, etc.) for bacteria. A good example is bacterial pneumonia. In the past (before antibiotics discovery) Streptococcus pneumoniae had four stages. One of the stages called the stage of red hepatisation was characterized by extravasation of erythrocytes which gave red color to consolidated lung and were colonized by S. pneumonia . These erythrocytes were giving bacteria protein, iron and other nutrients for growth and multiplication. If bacteria are attracted and engulfed by erythrocyte and survive inside erythrocyte the latter becomes bacteria pray. The same happens in case of hemorrhage: the lack of oxygen inside erythrocytes makes them vulnerable for pathogens and the hunter (erythrocyte) may become the pray (for pathogens) as it happens with leukocyte in case of incomplete phagocytosis. Deoxygenated hemoglobin cannot provide bacteria killing and as a result after attracting and engulfing a pathogen the latter may start to multiply having some advantages inside the erythrocyte, for instance, protection from the immune system, action of antibiotics, etc. Surviving inside erythrocyte pathogens also have access to all essential nutrients including hemoglobin iron - a very specific metabolic trophy for the pathogen (iron is indispensable for growth and proliferation of many bacteria and other microorganisms) [89-91].

\subsection{Bloodstream Killed Bacteria Decomposition and Digestion}

In bloodstream erythrocytes can rapidly engulf and kill bacteria but they can't decompose and digest them because they have no appropriate enzymes, intracellular components and mechanisms for that. Erythrocytes are very effective "devices" for bacteria killing but their antibacterial function is limited by killing only. After releasing killed bacteria back to plasma decomposition and digestion of killed bacteria take place in reticuloendothelial system (RES). Two main organs that perform this function are liver and spleen. The liver provides $80 \%$ of RES function [92, 93]. Kupffer cells are the major macrophage population of human body that has direct contact with the blood [94].

The spleen removes older and injured during bacteria killing erythrocytes from the circulation as well as cellular debris and microorganisms in case of their resistance to erythrocyte killing. The spleen is one of important immune organs [95]. The spleen is also unique because it is the only lymphoid organ specialized in the filtration of blood (the rest of lymphoid organs filter lymph). Additionally, the spleen contains the largest single aggregate of lymphoid tissue in the body, housing approximately one third of total circulating lymphocytes, thus with a vast number of them migrating through the spleen at any given time, surpassing the combined traffic of all lymph nodes in the body [96].

Bacteria often invade macro organism in billions. Killing and digesting living bacteria in RES is time consuming process whereas killing bacteria by erythrocyte takes not so much time and is more effective. Erythrocyte is the cell that provides oxygen to all other cells of human body and so erythrocyte contains more oxygen and reactive oxygen species than any other cell. High concentration of reactive oxygen species determines rapid killing of pathogens and so there is no another cell in human body that can kill bacteria as fast and effective as erythrocyte. It should be also taken into account that erythrocytes are the most numerous cells in human body: they are approximately a quarter of all cells [97] and considerably surpass the number of RES cells. Erythrocyte also spends less energy for bacteria killing in comparison with the cells of the liver and the spleen: erythrocyte reactive oxygen species are some kind of byproducts of respiratory function of erythrocyte and only a very little amount of energy and oxygen is spent for reactive oxygen species production. The last circumstance explains why reactive oxygen species production and bacteria killing doesn't interfere $\mathrm{O} 2$ - $\mathrm{CO} 2$ transport function of erythrocytes. Usually erythrocytes kill bacteria that then are digested in RES; in case of bacteria resistance to erythrocyte reactive oxygen species the cells of RES become the second line of antibacterial defense killing and digesting bacteria simultaneously. Too many bacteria may overload the liver and spleen causing their enlargement and injury.

\section{Conclusion}

Thus, erythrocyte is bloodstream main bacterial killer. Out of bloodstream erythrocyte may become bacteria pray providing the latter nutrients for growth and multiplication. Erythrocyte bactericidal effectiveness is maximal in arterial blood and minimal in venous blood. Bactericidal power of erythrocyte depends upon the amount of reactive oxygen species inside erythrocyte whereas bacteria resistance to reactive oxygen species is determined by the type of bacterial metabolism (aerobe, anaerobe), catalase production, capsule production, bacterial wall thickness, structure, chemical complexity, permeability, etc. Bacteria killed by erythrocyte 
and released back to plasma are engulfed and digested by the cells of RES, particularly, in the liver and the spleen. . In comparison with RES cells erythrocytes are more numerous and more effective and rapid bacteria killers.

\section{References}

[1] Minasyan H, Erythrocyte and blood antibacterial defense. Eur J Microbiol Immunol. 2014;4(2):138-3.

[2] Minasyan H, Erythrocyte and Leukocyte: Two Partners in Bacteria Killing. International Reviews of Immunology, 2014, (doi: 10.3109/08830185.2014.956359).

[3] Marchi SF, Bodenmuller M, Lai D, Seiler C. Pulmonary venous flow velocity patterns in 404 individuals without cardiovascular disease. Heart. 2001; 85(1): 23-9.

[4] Mason DT, Mills CJ, Schillingford JP, Braunwald E, Measurement of Instantaneous Blood Flow Velocity and Pressure in Conscious Man with a Catheter-Tip Velocity ProbeCirculation. 1969;40:603-14.

[5] Gardin JM, Burn CS, Childs WJ, Henry WL. Evaluation of blood flow velocity in the ascending aorta and main pulmonary artery of normal subjects by Doppler echocardiography. Am Heart J. 1984; Feb;107(2):310-9.

[6] Dominguez de Villota ED, Ruiz Carmona MT, Rubio JJ, de Andrés S. Equality of the in vivo and in vitro oxygen-binding capacity of haemoglobin in patients with severe respiratory disease. Br J Anaesth .1981; 53 (12): 1325-8.

[7] Costanzo, LS. Physiology. Hagerstwon, Philadelphia.MD: Lippincott Williams \& Wilkins;2007.

[8] Anthea M, Hopkins J, McLaughlin CW, Johnson S, Warner MQ, LaHart D, Wright JD. Human Biology and Health. Englewood Cliffs, New Jersey, USA: Prentice Hall; 1993.

[9] Voet, D. Fundamentals of Biochemistry, 3rd. ed., New York: John Wiley \& Sons; 2008.

[10] Gaetani GF, Ferraris AM, Rolfo M, Kirkman HN. Predominant role of catalase in the disposal of hydrogen peroxide within human erythrocytes. Blood. 1996;87:1595-99.

[11] Masuoka N, Sugiyama H, Ishibashi N, Wang DH, Masuoka T, Kodama H, Nakano T. Characterization of acatalasemic erythrocytes treated with low and high dose hydrogen peroxide: hemolysis and aggregation. $\mathrm{J}$ Biol Chem. 2006;281:21728-34.

[12] Demple B. Regulation of bacterial oxidative stress genes. Annu. Rev. Genet. 1991;25:315-37.

[13] Imlay JA. Cellular defenses against superoxide and hydrogen peroxide. Annu. Rev. Biochem. 2008;77:755-76.

[14] Gouet P, Jouve HM, Dideberg O. Crystal structure of Proteus mirabilis PR catalase with and without bound NADPH. J Mol Biol. 1995;249:933-954.

[15] Hakansson KO, Brugna M, Tasse L. The three-dimensional structure of catalase from Enterococcus faecalis. Acta Crystallogr D. 2004;60:1374-1380.
[16] Hillar A, Nicholls P, Switala J, Loewen PC. NADPH binding and control of catalase compound II formation: comparison of bovine, yeast, and Escherichia coli enzymes. Biochem J.1994;300:521-39.

[17] Chelikani P, Fita I, Loewen PC. Diversity of structures and properties among catalases. Cell Mol Life Sci. 2004;61:192208.

[18] Whittaker J. W. Non-heme manganese catalase - the 'other' catalase. Arch Biochem Biophys. 2012 Sep 15; 525(2): 11120 .

[19] Beyer WF, Fridovich I. Catalases - with and without heme. Basic Life Sci. 1988;49:651-61.

[20] Chelikani P, Fita I, Loewen PC. Diversity of structures and properties among catalases.Cell. Mol. Life Sci. 2004 Jan; 61 (2): 192-208.

[21] La Carbona S, Sauvageot N, Giard JC, Benachour A, Posteraro B, et al. Comparative study of the physiological roles of three peroxidases (NADH peroxidase, Alkyl hydroperoxide reductase and Thiol peroxidase) in oxidative stress response, survival inside macrophages and virulence of Enterococcus faecalis. Mol Microbiol. 2007;66:1148-63.

[22] Fick A: Ueber die Messung des Blutquantums in den Herzventrikeln. Verh Phys Med Ges Wurzburg. 1870;2:16-28.

[23] Barratt-Boyes B, Wood E: The oxygen saturation of blood in the venae cavae, right-heart chambers and pulmonary vessels of healthy subjects. J Lab Clin Med. 1957; 50:93-106.

[24] Hillman RS, Ault KA, Rinder HM. Hematology in Clinical Practice: A Guide to Diagnosis and Management (4 ed.). New York: McGraw-Hill Professional; 2005.

[25] Pierigè F, Serafini S, Rossi L, Magnani M. Cell-based drug delivery. Advanced Drug Delivery Reviews. 2008;60(2): 28695 .

[26] Marieb EN, Hoehn K. The Cardiovascular System:Blood Vessels. Human anatomy \& physiology, 9th ed. New Jersey: Pearson Education, Inc. 2013 p. 712.

[27] Chen YM, Lee HC, Chang CM, Chuang YC, Ko WC. Clostridium bacteremia: emphasis on the poor prognosis in cirrhotic patients. J Microbiol Immunol Infect. 2001 Jun;34(2):113-8.

[28] Gorbach SL. Clostridium perfringens and other clostridia. In: Gorbach SL, Bartlett JG, Blacklow NR, editors. Infectious diseases. 2nd ed. Philadelphia: W.B. Saunders; 1998. p. 192530 .

[29] Peranio VA, Cross SA, Goldstein EJC. Incidence and clinical significance of anaerobic bacteremia in a community hospital. CID 1993; 16:S288-91.

[30] Finegold SM. Anaerobic bacteria in human diseases, New York, Academic Press, 1977.

[31] Felsen J, Wolarsky W. Suppurative pylephlebitis with bacteremia in chronic ulcerative colitis. Ann Intern Med. 1950;33(1):211-16.

[32] Libby DB, Bearman G. Bacteremia due to Clostridium difficile - review of the literature. Intern J Infect Dis, 2009; Vol.13, Issue 5:305-9. 
[33] Jacobs A, Barnard K, Fishel R, Gradon JD. Extracolonic manifestations of Clostridium difficile infections. Presentation of 2 cases and review of the literature. Medicine (Baltimore). 2001;80(2):88-101.

[34] Wolf LE, Gorbach SL, Granowitz EV. Extraintestinal Clostridium difficile: 10 years' experience at a tertiary care hospital. Mayo Clin Proc. 1998;73:943-947.

[35] Garcia-Lechuz JM, Hernangomez S, San Juan R, Pelaez T, Bouza E. Extra-intestinal infections caused by Clostridium difficile. Clin Microbiol Infect. 2001;7(8):453-457.

[36] Feldman RJ, Kallich M, Weinstein MP. Bacteremia due to Clostridium difficile: case report and review of extraintestinal C. difficile infections. Clin Infect Dis. 1995;20(6):1560-1562.

[37] Gorbach SL. Clostridium perfringens and other clostridia. In: Gorbach SL, Bartlett JG, Blacklow NR, editors. Infectious diseases. 2nd ed. Philadelphia: W.B. Saunders; 1998. p. 1925 30 .

[38] Peranio VA, Cross SA, Goldstein EJC. Incidence and clinical significance of anaerobic bacteremia in a community hospital. CID 1993; 16:S288-91.

[39] Hallit RR, Afridi M, Sison R, Salem E, Boghossian J, Slim J. Clostridium tetani bacteraemia. J Med Microbiol. 2013 Jan;62(Pt 1):155-6.

[40] Lockhart PB, Brennan MT, Sasser HC, Fox PC, Paster BJ, Bahrani-Mougeot FK. Bacteremia associated with toothbrushing and dental extraction. Circulation. 2008; 117: 3118-3125.

[41] Little JW, Falace DA, Miller CS, Rhodus NL. Infective endocarditis. In: Dental management of the medically compromised patient. 6th edition. Toronto: Mosby, Inc.; 2002. p. 21-51.

[42] Forner L, Larsen T, Kilian M, Holmstrup P. Incidence of bacteremia after chewing, tooth brushing and scaling in individuals with periodontal inflammation. J Clin Periodontol. 2006 Jun;33(6):401-7.

[43] Hartzell JD, Torres D, Kim P, Wortmann G. Incidence of bacteremia after routine tooth brushing. Am J Med Sci. 2005; 329: $178-180$.

[44] Hall G, Hedstrцm SA, Heimdahl A, Nord CE. Prophylactic administration of penicillins for endocarditis does not reduce the incidence of postextraction bacteremia. Clin Infect Dis. 1993; 17: 188-194.

[45] Lockhart PB, Durack DT. Oral microflora as a cause of endocarditis and other distant site infections. Infect Dis Clin North Am. 1999; 13: 833-50.

[46] Tomas I, Alvarez M, Limeres J, Potel C, Medina J, Diz P. Prevalence,duration and aetiology of bacteraemia following dental extractions. Oral Dis. 2007 Jan;13(1):56-62.

[47] Takai S, Kuriyama T, Yanagisawa M, Nakagawa K, Karasawa $T$. Incidence and bacteriology of bacteremia associated with various oral and maxillofacial surgical procedures. Oral Surg Oral Med Oral Pathol Oral Radiol Endod. 2005 Mar;99(3):292-8.

[48] Mandal BK, Brennand J. Bacteraemia in salmonellosis: a 15 year retrospective study from a regional infectious diseases unit. BMJ. 1988; 297:1242.

[49] Preveden T, Knezević K, Brkić S, Jelesić Z. Salmonella bacteremia. Med Pregl. 2001 Jul-Aug;54(7-8):367-70.

[50] de Jong HK, Parry CM, van der Poll T, Wiersinga WJ. Hostpathogen interaction in invasive Salmonellosis. PLoS Pathog. 2012;8(10):e1002933.

[51] Tsolis RM, Young GM, Solnick JV, Baumler AJ. From bench to bedside: stealth of enteroinvasive pathogens. Nat Rev Microbiol. 2008;6: 883-92.

[52] Gruner BM, Han SR, Meyer HG, Wulf U, Bhakdi S, Siegel EK. Characterization of a Catalase-Negative MethicillinResistant Staphylococcus aureus strain. J Clin Microbiol. 2007;1:2684-85.

[53] WE, Bannerman. TL. In: Staphylococcus and Micrococcus. Manual of clinical microbiology. 7th ed. Murray PR, et al., editors. Washington, DC: ASM Press; 1999. p. 264-282.

[54] Sanz R, Marn I, Ruiz Santa Quiteria JA, Orden JA, Cid D, et al RM Diez. Catalase deficiency in Staphylococcus aureus subsp. anaerobius is associated with natural loss-of-function mutations within the structural gene. Microbiology. 2000;146:465-75.

[55] Mylotte JM, McDermott C, Spooner JA. Prospective study of 114 consecutive episodes of Staphylococcus aureus bacteremia. Rev Infect Dis. 1987; 9:891.

[56] Shurland S, Zhan M, Bradham DD, Roghmann MC. Comparison of mortality risk associated with bacteremia due to methicillin-resistant and methicillin-susceptible Staphylococcus aureus. Infect Control Hosp Epidemiol. 2007; 28:273.

[57] Luderitz O, Jann K, Wheat R. Somatic and capsular antigens of gram-negative bacteria. Comp Biochem Physiol. 1968;A26:105-28.

[58] Smith H. Microbial surfaces in relation to pathogenicity. Bacteriol Rev. 1977;41:475-500.

[59] Timmis KNG, Boulnois J, Bitter-Suermann D, Cabello FC. Surface components of Escherichia coli that mediate resistance to the bactericidal activity of serum and phagocytes. Curr Top Microbiol Immunol. 1985;118:197-18.

[60] Bortotussi R. Capsular KI polysaccharide of Escherichia coli: relationship to virulence in newborn rats and resistance to phagocytosis. Infect Immun. 1978; 25:293-8.

[61] Karakawa WW, Vann WF. Capsular polysaccharides of Staphylococcus aureus. Semin Infect Dis. 1982;4:285-3.

[62] Hochkeppel HK, Brau D, Vischer GW, Sutter U, Staeubli R, Guggenheim EL et al. Serotyping and electron microscopy studies of Staphylococcus aureus clinical isolates with monoclonal antibodies to capsular polysaccharide types 5 and 8. J. Clin Microbiol. 1987;25:526-30.

[63] Lee JC, Liu MJ, Parsonnet J, Arbeit RD. Expression of type-8 capsular polysaccharide and production of toxic shock syndrome toxin-1 are associated among vaginal isolates of Staphylococcus aureus. J Clin Microbiol. 1990;28:2612-15.

[64] Schmid EN, Menge B, Lickfeld KG. Capsule fine structure in thin slices of Klebsiella pneumoniae. J Ultrastruct Res. 1981;75:41-9.

[65] Holmes RL, Kozinn WP. Pneumonia and Bacteremia Associated with Haemophilus influenzae Serotype d. J Clin Microbiol. 1983 Sep; 18(3):730-2. 
[66] Laupland KB, Gregson DB, Zygun DA. Severe bloodstream infections: a population-based assessment. Crit Care Med. 2004;32:992-7.

[67] Spinosa MR, Progida C, Talà A, Cogli L, Alifano P, Bucci C. The Neisseria meningitides: Capsule Is Important for Intracellular Survival in Human Cells. Infect Immun. July 2007; vol. 75 no.7 :3594-3603.

[68] Morona JKD, Miller C, Morona R, Paton JC. The effect that mutations in the conserved capsular polysaccharide biosynthesis genes cpsA, cpsB, and cpsD have on virulence of Streptococcus pneumoniae. J Infect Dis. 2004;189:1905-13.

[69] Morona JK, Morona R, Paton JC. Attachment of capsular polysaccharide to the cell wall of Streptococcus pneumoniae type 2 is required for invasive disease. Proc Natl Acad Sci U. S. A. 2006;103:8505-10.

[70] Vidal F, Mensa J, Almela M. Epidemiology and outcome of Pseudomonas aeruginosa bacteremia, with special emphasis on the influence of antibiotic treatment. Analysis of 189 episodes. Arch Intern Med. 1996;156:2121.

[71] Wisplinghoff $H$, Bischoff $T$, Tallent SM. Nosocomial bloodstream infections in US hospitals: analysis of 24,179 cases from a prospective nationwide surveillance study. Clin Infect Dis. 2004;39:309.

[72] Hogevik H, Olaison L, Andersson R, Lindberg J, Alestig K. Epidemiologic aspects of infective endocarditis in an urban population. A 5-year prospective study. Medicine (Baltimore). 1995 Nov;74(6):324-39.

[73] Beck J, Garcia R, Heiss G, Vokonas PS, Offenbacher S. Periodontal disease and cardiovascular disease. J Periodontol. 1996 Oct;67(10 Suppl):1123-37.

[74] Beck JD, Slade G, Offenbacher S. Oral disease, cardiovascular disease and systemic inflammation. Periodontol. 2000;23:110-20.

[75] Genco RJ, Wu TJ, Grossi S. Periodontal microflora related to the risk for myocardial infarction: A case control study. J Dent Res. 1999;78:457.

[76] Clough M. The cultivation of tubercle bacilli from the circulating blood in miliary tuberculosis. Am Rev Tuberculosis. 1917;1: $598-621$.

[77] Stead W, Bates J. Evidence of a "silent" bacillemia in primary tuberculosis. Ann Intern Med. 1971; 74: 559 -561.

[78] El Sahly HM, Teeter LD, Musser JM, Graviss EA. Mycobacterium tuberculosis bacteraemia: experience from a non-endemic urban centre. Clin Microbiol Infect. 2014 Mar;20(3):263-8.

[79] McDonald L, Archibald L, Rheanpumikankit S. et al. Unrecognised Mycobacterium tuberculosis bacteraemia among hospital inpatients in less developed countries. Lancet. 1999; 354: $1159-63$.

[80] Jackett P S, Aber V R, Lowrie D B. Virulence and resistance to superoxide, low $\mathrm{pH}$ and hydrogen peroxide among strains of Mycobacterium tuberculosis. J Gen Microbiol. 1978;104:37-45.
[81] Mitchison D A, Selkon J B, Lloyd J. Virulence in the guineapig, susceptibility to hydrogen peroxide, and catalase activity of isoniazid-sensitive tubercle bacilli from South Indian and British patients. J Pathol Bacteriol. 1963;86:377-86.

[82] Heym B, Zhang Y, Poulet S, Young D, Cole S T. Characterization of the $k a t G$ gene encoding a catalaseperoxidase required for the isoniazid susceptibility of Mycobacterium tuberculosis. J Bacteriol. 1993;175:4255-59.

[83] Drutz DJ, Chen TSN, Lu WH. The continuous bacteremia of lepromatous leprosy. N Engl J Med. 1972; 287: 159-64.

[84] Sengupta U, Ramu G, Desikan KV. Evaluation of bacteremia in leprosy patients. Lepr India. 1978; 50: 381-7.

[85] Padma MN, Desikan KV. Bacillaemia in leprosy. Indian J Med Res. 1975; 63: 888-92.

[86] Beveridge TJ. Mechanism of Gram variability in select bacteria. J Bacteriol. 1990;172:1609-1620.

[87] Brock T D, Madigan M T, Martinko J M, Parker J. Biology of microorganisms. 7th ed. Englewood Cliffs, N.J: Prentice-Hall International, Inc.; 1994.

[88] Davies J A, Anderson G K, Beveridge T J, Clark H C. Chemical mechanism of the Gram stain and synthesis of a new electron-opaque marker for electron microscopy which replaces the iodine mordant of the stain. J Bacteriol.1983;156:837-845.

[89] Ratledge C, Dover LG. Iron metabolism in pathogenic bacteria. Annu Rev Microbiol. 2000;54: 881-941.

[90] Andrews SC, Robinson AK, Rodriguez-Quinones F. Bacterial iron homeostasis. FEMS Microbiol Rev. 2003;27:215-37.

[91] Bullen JJ, Rogers HJ, Spalding PB, Ward CG. Iron and infection: the heart of the matter. FEMS Immunol Med Microbiol. 2005;43: 325-30.

[92] Biozzi G, Stiffel C. The physiopathology of the reticuloendothelial cells of the liver and the spleen. In: Popper, H. and Shaffner, F. (Eds): Progress in liver diseases. New York: Grune \& Stratton;1965. p.166-9.

[93] Biozzi G, Benacerraf B, Halpern BN. Quantitative study of the granulopoetic activity of the reticuloendothelial system II. A study of the kinetics of the granulopoetic activity of the RES in relation to the dose of carbon injected. Relationship between the weight of the organs and their activity. Br J Exp Pathol.1953; 34: 441-8.

[94] Wanless IR. Physioanatomic considerations. In: Schiff, E.R., Sorrell, M.F., Maddrey, W.C. (Eds.), Schiff's Diseases of the Liver. Philadelphia: Lippincott-Raven; 1999.p. 3-38.

[95] Mebius RE, Kraal G, Structure and function of the spleen. Nature Reviews Immunology. 2005 August;5: 606-16.

[96] Bowdler A: The Complete Spleen: Structure, Function and Clinical Disorders.2nd edition. New Jersey: Humana Press; 2002.

[97] Pierigè F, Serafini S, Rossi L, Magnani M . Cell-based drug delivery. Advanced Drug Delivery Reviews. 2008 January; 60 (2): 286-95. 